\title{
Desmoplastic small round cell tumor of the parotid gland-report of a rare case and a review of the literature
}

\author{
Kanako C. Hatanaka 1*, Emi Takakuwa1', Yutaka Hatanaka', Akira Suzuki², Satoshi Ilzuka², Nayuta Tsushima ${ }^{3}$, \\ Tomoko Mitsuhashi ${ }^{1}$, Shintaro Sugita ${ }^{4}$, Akihiro Homma ${ }^{5}$, Shojiroh Morinaga ${ }^{6}$, Tadashi Hashegawa ${ }^{5}$ \\ and Yoshihiro Matsuno ${ }^{1}$
}

\begin{abstract}
Background: Desmoplastic small round cell tumor (DSRCT) is a rare soft tissue tumor that generally involves the retroperitoneum, pelvis, omentum and mesentery in younger patients. However, extra-abdominal DSRCT is very rare.

Case presentation: A 49-year-old Japanese man noticed a mass in the right parotid gland. Ultrasound examination revealed a solid tumor about $2 \mathrm{~cm}$ in diameter. Computed tomography (CT) of the whole body revealed no other tumors or lymph node swelling. Superficial parotidectomy was performed. Histologically, the tumor was composed of various-sized tumor cell nests in an abundant fibromyxoid and collagenous background. The tumor cells were small to medium-sized. Immunohistochemistry showed that the tumor cells were immunoreactive for epithelial markers and desmin. They also showed strong nuclear staining with a Wilms tumor 1 (WT1) antibody detecting the C-terminal region (C-WT1), but not the N-terminal region (N-WT1). We also performed 3'/5' expression imbalance assay based on reverse transcription polymerase chain reaction (RT-PCR) to determine whether aberrant WT1 gene expression was present. This tumor was found to lack 5'-regional expression of the WT1 gene, as well as immunoreactivity with the NWT1 antibody. Finally, fluorescence in situ hybridization (FISH) and RT-PCR analyses revealed the presence of a gene showing fusion between exon 7 of EWSR1 and exon 8 of WT1. The tumor was diagnosed as a DSRCT of the right parotid gland. The patient has been followed for 3 years without recurrence or metastasis.

Conclusions: Although DSRCT in the salivary gland is extremely rare, it should be included in the differential diagnosis of poorly differentiated salivary gland neoplasms, especially with a fibromyxoid background. Pathologists should bear in mind that DSRCT may occur in major salivary glands and should perform immunohistochemistry with appropriate antibodies, not only those against keratin and desmin, but also one detecting the C-terminal region of WT-1. Furthermore, molecular detection of EWSR1-WT1 fusion gene conclusively confirmed the diagnosis of DSRCT in this uncommon location.
\end{abstract}

Keywords: Desmoplastic small round cell tumor, Salivary gland, WT1, C-terminal region, 3'/5' expression imbalance assay

\footnotetext{
* Correspondence: kyanack@huhp.hokudai.ac.jp

${ }^{1}$ Department of Surgical Pathology, Hokkaido University Hospital, N14W4,

Kita-ku, Sapporo, Japan

Full list of author information is available at the end of the article
}

(c) The Author(s). 2019 Open Access This article is distributed under the terms of the Creative Commons Attribution 4.0 International License (http://creativecommons.org/licenses/by/4.0/), which permits unrestricted use, distribution, and reproduction in any medium, provided you give appropriate credit to the original author(s) and the source, provide a link to the Creative Commons license, and indicate if changes were made. The Creative Commons Public Domain Dedication waiver (http://creativecommons.org/publicdomain/zero/1.0/) applies to the data made available in this article, unless otherwise stated. 


\section{Background}

Desmoplastic small round cell tumor (DSRCT) is rare and a highly aggressive neoplasm that typically involves the soft tissues of the abdomen or pelvis in children or young adults, showing a male predilection. Although it occurs over a wide age range, the peak incidence is in the third decade of life. DSRCT usually shows widespread abdominal serosal involvement, and overall patient survival is poor. On the other hand, extra-abdominal DSRCT is very rare. Previous cases have been reported to arise in the lung [1], pleura [2], paranasal sinuses [3], central nervous system [4], and scalp soft tissue [5] . DSRCT in major salivary glands has been reported, but it is extremely rare. To our knowledge, only 5 cases occurring in the salivary gland have been reported in the English literature [6-10]. Here, we report a case of a primary parotid gland DSRCT in a 49-year-old man, who is the oldest patient known to have been affected by this tumor, and who has survived for 3 years without recurrence. We also summarize the clinicopathological features of DSRCT in the salivary gland.

\section{Case presentation}

\section{Clinical features}

A 49-year-old Japanese man noticed a mass in the right parotid gland without pain. There was no history of weight loss, fever, or night sweats. Ultrasound examination demonstrated that the tumor was a solid mass about $2 \mathrm{~cm}$ in diameter. T1-weighted magnetic resonance imaging showed a low-intensity, well-defined mass in the right parotid gland unaccompanied by lymph node swelling (Fig. 1). Abdominal computer tomography (CT) and

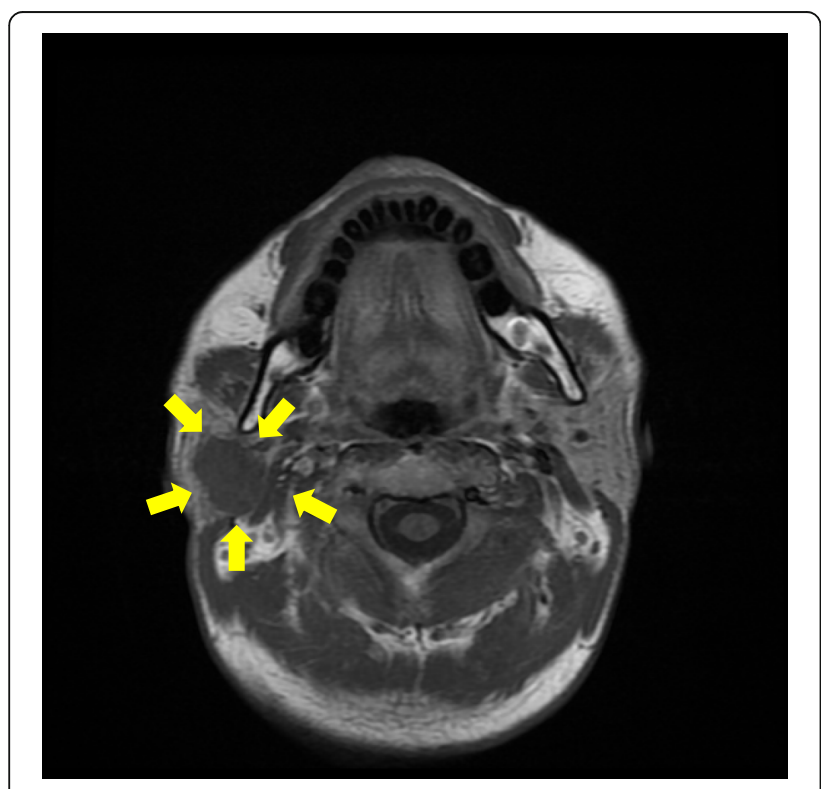

Fig. $1 \mathrm{~T} 1$-weighted magnetic resonance imaging (MRI) showing a low-enhanced, well-defined mass in the right parotid gland (arrow) whole-body positron emission tomography (PET) scan revealed no other tumor elsewhere. Although fine-needle aspiration was performed several times, it was difficult to obtain tumor cells for diagnosis, except for cells from normal salivary glands. Superficial parotidectomy was therefore performed and the tumor was successfully resected without facial nerve paralysis. After parotidectomy, the patient received radiotherapy and is currently alive and well with no evidence of recurrence after 3 years.

\section{Pathological findings}

Grossly, the tumor occupied the superficial lobe of the right parotid gland, and was solid and firm, measuring $2.7 \times$ $2.7 \times 2.3 \mathrm{~cm}$. It was well circumscribed without a fibrous capsule, and the cut surface was grayish tan in color showing some lobulation at the tumor borders (Fig. 2a). Macroscopic necrosis or intratumoral hemorrhage was not evident. Histologically, the tumor predominantly showed a border that was well-defined from the surrounding tissue, although it was focally infiltrative in some areas. There was no fibrous capsule around the tumor. The tumor was composed of sharply demarcated cellular nests of various-sizes, growing in a paucicellular fibromyxoid or collagenous stroma (Fig. 2b). The tumor cells were round to polygonal and small to medium-sized, with scant cytoplasm and hyperchromatic irregular round nuclei with granular chromatin (Fig. 2c). Tumor cells with clear cytoplasm were also found in tumor nests, but rhabdoid cells were not identified. Apoptotic bodies were occasionally found, but necrotic foci were not evident. Venous invasion was detected (Fig. 2d). Some non-neoplastic salivary ducts were found between tumor nests, demonstrating that the tumor infiltration had extended within the parotid parenchyma. There was no evidence of regional lymph node metastasis.

\section{Immunohistochemical findings}

An immunohistochemical study was performed using formalin-fixed paraffin embedded (FFPE) sections of representative tumor blocks, using the antibodies summarized in Table 1 . The tumor cells were positive for cytokeratin (AE1/AE3, CK8/18), EMA, vimentin, desmin, and focally positive for CD56 (Fig. 2e). Desmin immunoreactivity showed a diffuse cytoplasmic pattern for the most part, as well as a paranuclear dot-like pattern in a smaller proportion of the tumor (Fig. 2f). The cells were negative for chromogranin A, synaptophysin, S100 protein, CK5/6, p63, CD99 (MIC2), GFAP, and CD117 (KIT). They were also negative for calponin and $\alpha$-smooth muscle actin ( $\alpha S M A)$, in contrast to the positivity shown by myofibroblast-like spindle cells in the stroma. The Ki-67 labeling index was almost 50\%. For WT1, the tumor cells showed strong nuclear staining with an antibody recognizing the C-terminal region of WT1 (C-WT1) (polyclonal, Abnova). However, neither of two N-terminal 

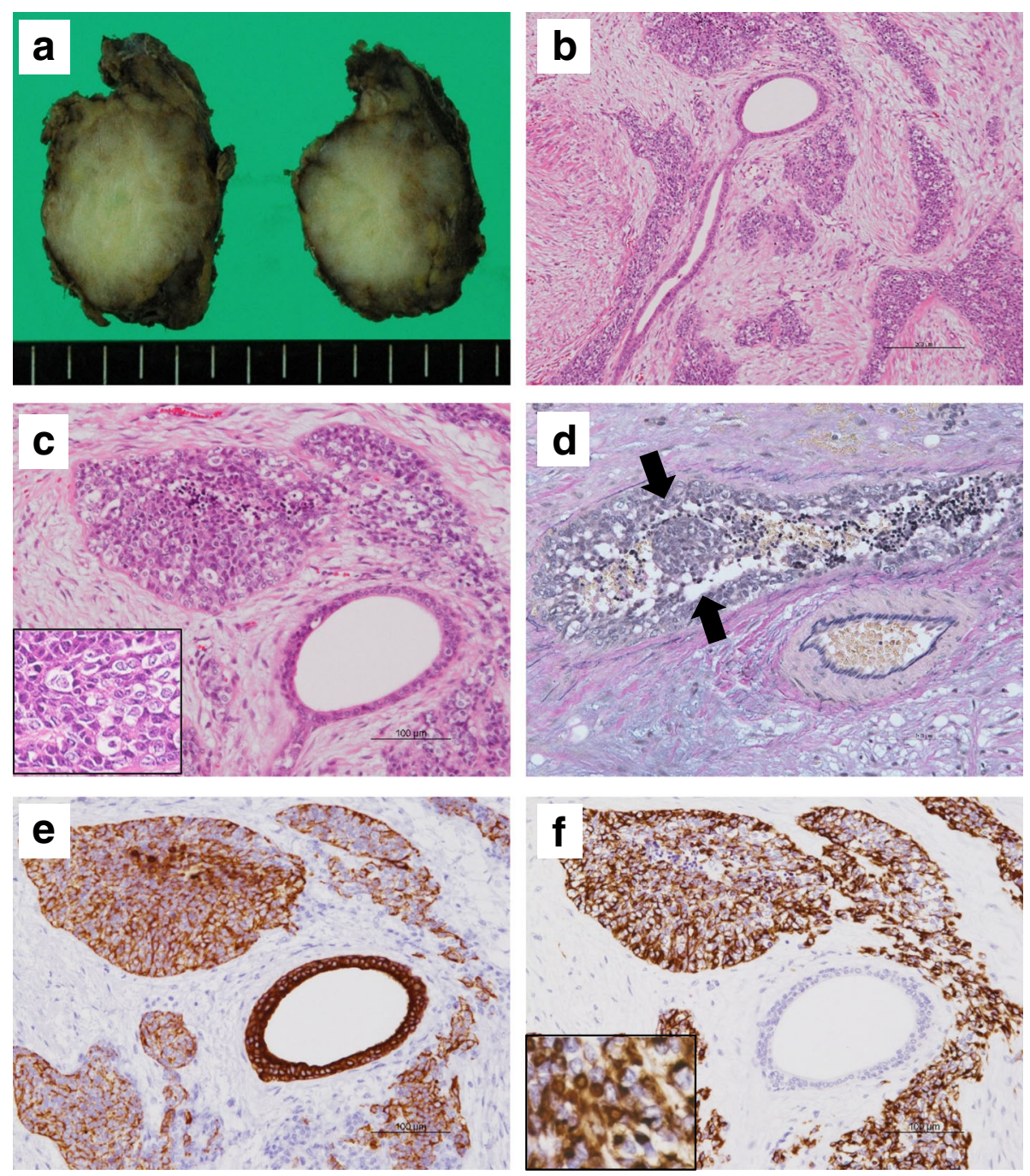

Fig. 2 Macroscopic and histological findings of the salivary gland tumor. a The resected right parotid gland mass, appearing as a firm tan-colored tumor. b Well-defined nests of tumor cells varying in size are separated by a fibromyxoid stroma. (Hematoxylin-eosin, scale bar: $200 \mu \mathrm{m})$. c The nests are composed of small blue cells with scant cytoplasm and medium-sized cells with clear cytoplasm (insert). The normal salivary glands can be seen adjacent to the tumor nests. (scale bar: $100 \mu \mathrm{m}$ ). d Venous invasion (arrows) is evident (Elastica van Gieson staining). e Immunohistochemistry of the tumor cells shows positivity for CK8/18. f The tumor cells also show diffuse cytoplasmic positivity for desmin, although focal dot-like paranuclear positivity is also seen (inset)

antibodies (N-WT1), WT49 (Leica) nor 6F-H2 (Dako), elicited positive nuclear staining, although the latter showed nonspecific cytoplasmic staining, (Fig. 3a-c).

\section{Molecular analyses}

Dual-colored fluorescence in situ hybridization (FISH) analysis using EWSR1 break-apart probes (Abbott Molecular, Abbott Park, IL) on FFPE tissue detected EWSR1 split signals in $94 \%$ of the tumor cells (Fig. 3d). We then performed $3^{\prime} / 5^{\prime}$ expression imbalance assay based on reverse transcription polymerase chain reaction (RT-PCR) according to the methods described by Suehara et al [11], in order to determine whether aberrant WT1 gene expression was present. The result clearly showed that $5^{\prime}$-regional expression of the WT1 gene was lacking in the tumor (Fig. 3e), being consistent with absence of immunoreactivity with the N-WT1 antibody at the protein level revealed by immunohistochemistry (Fig. 3b-c). To confirm these gene alterations, RT-PCR for the EWSR1-WT1 fusion gene was performed using a forward primer (5'-TCCTACAGCCAAGCTCCAAGT-3', EWSR1 exon 7) and reverse primer (5'-ACCTTCGGTTCACAGTCCTTG-3', WT1 exon 8) [12]. This revealed the characteristic EWSR1-WT1 fusion gene (Fig. 3f). 
Table 1 List of Antibodies

\begin{tabular}{|c|c|c|c|}
\hline Antibody & Clone & Source & Dilution \\
\hline AE1/AE3 & E29 & DAKO & $1: 500$ \\
\hline CK8/18 & $5 \mathrm{D} 3$ & Nobocastra & $1: 200$ \\
\hline CK5/6 & D5/16/B4 & DAKO & $1: 400$ \\
\hline EMA & E29 & DAKO & $1: 500$ \\
\hline vimentin & V9 & Roche & RTU \\
\hline desmin & DER11 & Roche & RTU \\
\hline aSMA & $1 \mathrm{~A} 4$ & DAKO & $1: 300$ \\
\hline calponin & $\mathrm{hCP}$ & SIGMA & $1: 30000$ \\
\hline chromogranin A & LK2H10 & Roche & RTU \\
\hline synaptophysin & $27 G 12$ & Leica & RTU \\
\hline S100 protein & polyclonal & DAKO & $1: 5000$ \\
\hline CD56 & CD564 & Leica & RTU \\
\hline p63 & $7 J U L$ & Leica & RTU \\
\hline CD99 (MIC-2) & $12 \mathrm{E} 7$ & DAKO & $1: 100$ \\
\hline GFAP & polyclonal & DAKO & $1: 2000$ \\
\hline CD117 (c-Kit) & polyclonal & DAKO & $1: 500$ \\
\hline Ki-67 & MIB1 & DAKO & $1: 200$ \\
\hline WT1 & polyclonal & Abnova & $1: 5000$ \\
\hline WT1 & WT49 & Leica & $1: 100$ \\
\hline WT1 & $6 \mathrm{~F}-\mathrm{H} 2$ & DAKO & $1: 100$ \\
\hline
\end{tabular}

aSMA a-smooth muscle actin, EMA epithelial membrane antigen, WT1 Wilms tumor 1, GFAP glial fibrillary acidic protein, RTU ready-to-use

\section{Discussion}

DSRCT is an uncommon malignant neoplasm that first described in two boys in 1989 [13]. DSRCT occurs mainly in the abdominal cavity, retroperitoneum, and pelvis, but Gerald et al. reported that $6 \%$ of DSRCTs can occur in an extra-abdominal location [14]. Histologically, DSRCT is characterized by various-sized nests composed of small neoplastic cells with a prominent desmoplastic, fibromyxoid, or collagenous stroma. Immunohistochemically, DSRCT shows a distinctive and characteristic pattern of multi-phenotypic differentiation. Tumor cells express proteins associated with epithelial, muscular and neural differentiation. The distinctive dot-like staining pattern of desmin is typical, but a diffuse cytoplasmic pattern has also been described [7], as seen in the present case. Hill et al. reported that nuclear immunoreactivity with C-WT1 antibody, which was observed in this case and is considered attributable to EWSR1-WT1 gene fusion, is useful for differentiating DSRCT from other small blue cell tumors, such as Ewing sarcoma [9]. The variable immunohistochemical reactivity of WT1 protein according to the anti-WT1 antibody employed may be a diagnostic pitfall. Obviously, it is critically important to use C-WT1 antibody for diagnosis of DSRCT, because N-WT1 antibody would give negative results, as was confirmed by the lack of the $5^{\prime}$-regional expression of the $W T 1$ gene in the present case.

Although the present case showed typical histological features and immunohistochemical profiles, successful detection of the EWSR1-WT1 gene rearrangement involving $\mathrm{t}(11,22)(\mathrm{q} 13 ; \mathrm{q} 12)$ by FISH and RT-PCR assays using FFPE tissues conclusively confirmed the diagnosis of DSRCT in this uncommon location.

The clinicopathological features of salivary gland DSRCT reported previously in the English literatures are summarized in Table 2. All 6 cases, including the present one, occurred in males, and the age at the diagnosis ranged from 5 to 49 years, with a median age of 28 years. Two of these cases occurred in the fifth decade, although DSRCT is generally considered as a differential diagnosis in children or young adults. The tumors ranged in size from 2.7 to $5 \mathrm{~cm}$, with an average of $4.1 \mathrm{~cm}$. Among the six patients, three were still undergoing follow-up, and one had died due to systemic metastasis. Salivary gland DSRCT showed histological features similar to those of abdominal DSRCT. The overall survival in abdominal DSRCT patients is generally poor, despite multimodality therapy [15], According to the present case as well as previous cases, only one among 6 patients with salivary gland DSRCT died due to metastasis. The prognosis of salivary gland DSRCT is unclear because of its rarity, but early detection or complete resection of salivary gland DSRCT might result in better prognosis.

The origin of DSRCT remains unclear. It has been speculated that DSRCTs are derived from mesothelial or submesothelial cells because a vast majority of patients develop DSRCTs in cavities that are lined with mesothelial cells or because tumor cells show immunohistochemical positivity for epithelial and mesenchymal antigens including desmin, and WT-1 [12].

DSRCT is not usually included in the differential diagnosis in primary salivary gland tumors in view of its rarity. Because DSRCT is composed of small nests with cohesive small to medium-sized cells and shows immunoreactivity for epithelial markers, it might be diagnosed as carcinomas, such as small cell carcinoma, poorly differentiated carcinoma, undifferentiated carcinoma, without staining for desmin. Primary small cell carcinoma of the salivary glands is also rare, accounting for approximately $2 \%$ of all salivary gland tumors, and most arise in patients 50 years old or more [16]. Positivity for synaptophysin or chromogranin is useful for identification of small cell carcinoma. It is also difficult to rule out poorly differentiated carcinoma or undifferentiated carcinoma, although an abundant desmoplastic or fibromyxoid stroma is an unusual feature in these carcinomas. Therefore, this 

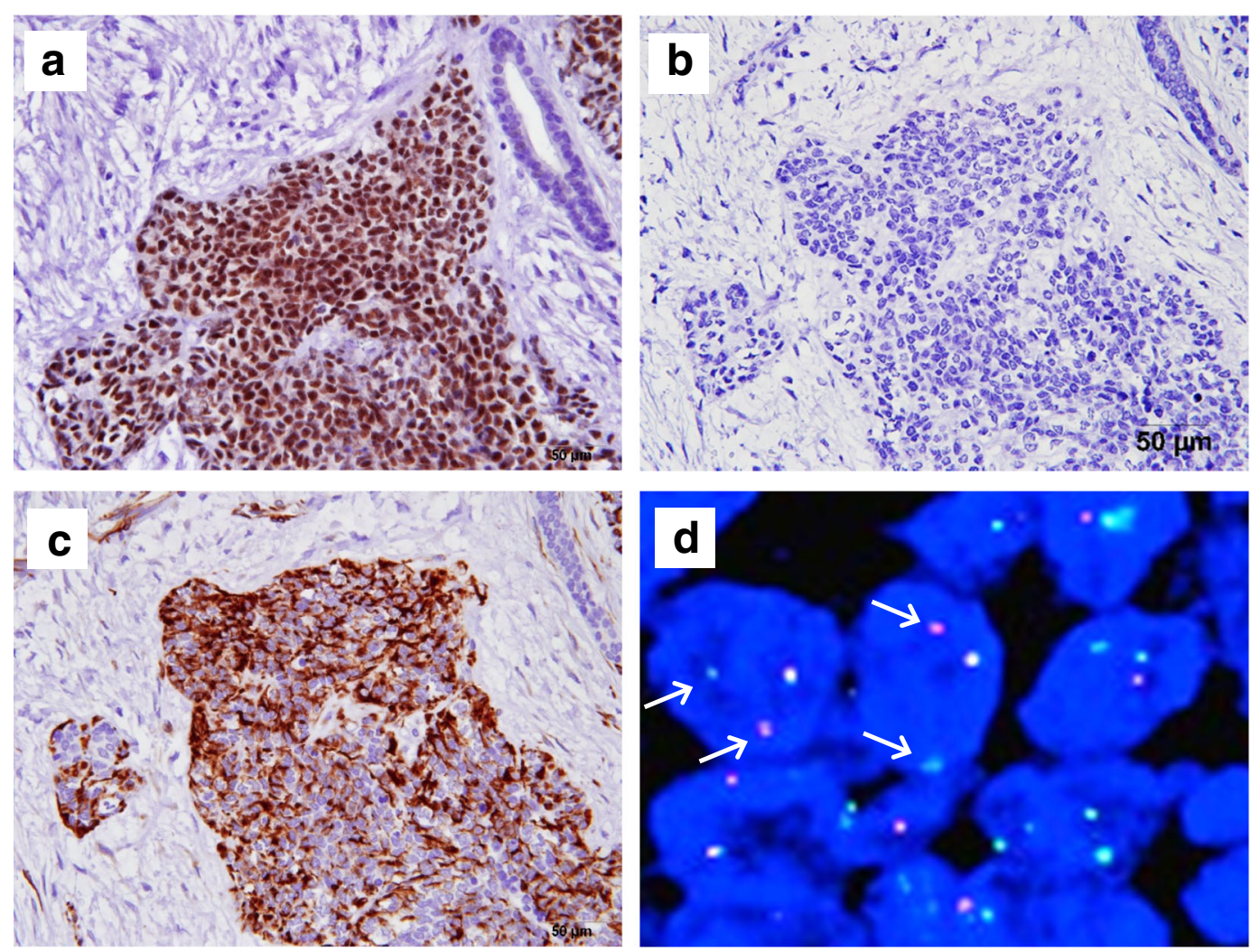

e
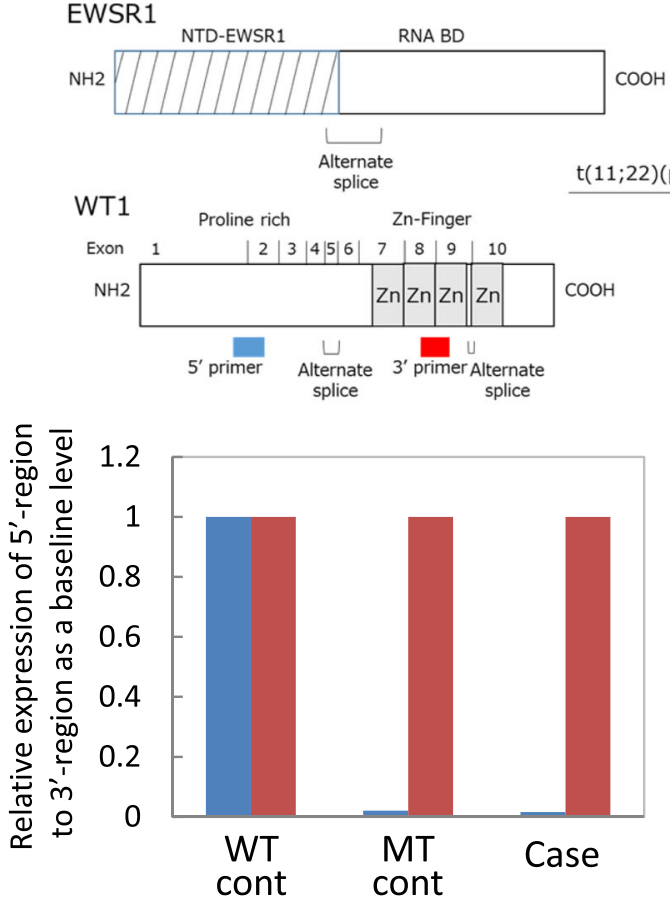

घ 5 ' region $\quad$ 3'-region

EWSR1-WT1

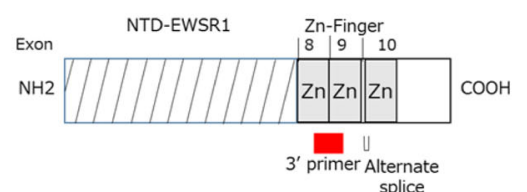

f
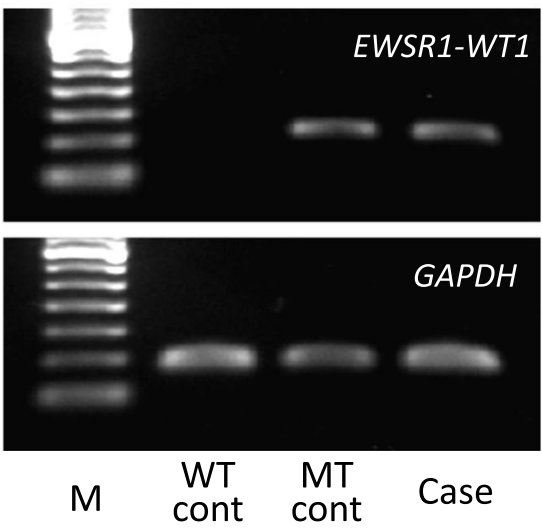

Fig. 3 (See legend on next page.) 
(See figure on previous page.)

Fig. 3 Immunohistochemical findings and molecular analyses of the salivary gland tumor. a C-WT1 shows nuclear positivity (scale bar: $50 \mu \mathrm{m})$. b NWT1 (WT49) shows nuclear and cytoplasmic negativity. c N-WT1(6F-H2) shows cytoplasmic positivity. $\mathbf{d}$ FISH analysis using a break-apart probe for the EWSR1 gene region demonstrates the rearrangement in most of the cells. e The $3^{\prime} / 5^{\prime}$ expression imbalance assay based on RT-PCR reveals that the tumor lacked 5'-regional expression of the WT1 gene. The primers were designed to measure the expressions at two regions for each gene transcript: a $5^{\prime}$ probe pair located far upstream of the exons and a second pair located within the exons located further $3^{\prime}$ in the WT1 gene. PCR analysis was performed using these $5^{\prime}$ and $3^{\prime}$ primers, respectively. The Ct data were normalized to wild-type control tissue, and the normalized data was expressed as the relative gene expression level. WT cont; wild-type control (ovarian serous carcinoma), MT cont; mutant type control (typical DSRCT). f RT-PCR analysis showed that the EWS-WT1 fusion gene was present in the sample. M; marker, WT cont and MT cont; same as above

might be a diagnostic clue for DSRCT. Other differential diagnosis, such as malignant melanoma, metastatic neuroblastoma, or lymphoma, are excluded with positivity for epithelial markers. Merkel cell carcinoma is also the differential diagnosis, but it is excluded with staining for neuroendocrine markers and its characteristic dot-like staining pattern for cytokeratin 20.

Primary non-lymphoid mesenchymal neoplasms of major salivary glands are also rare and account for only $1.9-5 \%$ of cases [8]. Most mesenchymal tumors are benign. The most common mesenchymal tumor is lipoma, [8] [17]. Malignant cases are extremely rare [8]. Because of the histological features of small round cell tumors, Ewing sarcoma and rhabdomyosarcoma are also included as differential diagnoses. Positivity for desmin and WT1 nuclear staining in addition to positive epithelial markers strongly favors a diagnosis of DSRCT over that of Ewing sarcoma and rhabdomyosarcoma. Furthermore, molecular biology studies are useful and important in differentiating DSRCT from Ewing sarcoma and rhabdomyosarcoma. In the present case, the tumor nests were composed of not only small-sized cells with a high nuclear/cytoplasmic ratio, but also medium-sized cells with clear cytoplasm. These cells with clear cytoplasm were also described in a previous report [6]. Because both two cell types share the same immunohistochemical profiles in the present case, cells with clear cytoplasm should also be recognized as neoplastic, and not as non-neoplastic bystander cells such as myoepithelial cells.

\section{Conclusions}

In summary, we have reported a rare primary DSRCT with venous invasion arising from the parotid glands of a middle-aged man. It is very important to be aware of the fact that DSRCT may occur in major salivary glands. To ensure accurate diagnosis with immunohistochemistry, desmin and the C-terminal region of WT1 are very useful markers in addition to epithelial markers. Furthermore, molecular detection of EWSR1-WT1 fusion gene conclusively confirmed the diagnosis of DSRCT in this uncommon location.

Table 2 Clinicopathological summary of Major Salivary Gland DSRCT

\begin{tabular}{|c|c|c|c|c|c|c|c|c|c|}
\hline Authors & $\begin{array}{l}\text { Age (y) } \\
\text { Sex }\end{array}$ & $\begin{array}{l}\text { Salivary } \\
\text { gland }\end{array}$ & Size $(\mathrm{cm})$ & $\mathrm{HC}+$ & $\begin{array}{l}\text { Molecular } \\
\text { test }\end{array}$ & $\begin{array}{l}\text { Lymph node } \\
\text { metastasis }\end{array}$ & $\begin{array}{l}\text { Resection } \\
\text { margin }\end{array}$ & $\begin{array}{l}\text { Additional therapy } \\
\text { after operation }\end{array}$ & $\begin{array}{l}\text { Outcome } \\
\text { (mo) }\end{array}$ \\
\hline Pang et al & $41 / M$ & $\begin{array}{l}\text { Left } \\
\text { submandibular }\end{array}$ & 5 & $\begin{array}{l}\text { Desmin, EMA, } \\
\text { CK, WT1, CD56 }\end{array}$ & FISH, RT-PCR & Positive & Negative & ND & 1 (DOC) \\
\hline Yin et al & $24 / M$ & $\begin{array}{l}\text { Right } \\
\text { submandibular }\end{array}$ & 4 & $\begin{array}{l}\text { Desmin, Vimentin, } \\
\text { CK, NSE, p53 }\end{array}$ & FISH, RT-PCR & NS & Negative & Chemo, RT & 7 (AFD) \\
\hline Cho et al & $26 / M$ & Left sumandibular & 4 & $\begin{array}{l}\text { Desmin, CK, NSE, } \\
\text { Vimentin }\end{array}$ & RT-PCR & Positive & NS & Chemo, RT & $\begin{array}{l}23 \text { (DOD) } \\
\text { systemic } \\
\text { metastasis }\end{array}$ \\
\hline Hill at al & $5 / M$ & Parotid & NS & $\begin{array}{l}\text { Desmin, EMA, WT1, } \\
\text { CK, NSE, vimentin }\end{array}$ & $\begin{array}{l}\text { FISH, RT-PCR, } \\
\text { Southern blot }\end{array}$ & NS & NS & & NS \\
\hline Wolf et al & $23 / M$ & Left parotid & 5 & $\begin{array}{l}\text { Desmin, EMA, } \\
\text { CK, NSE }\end{array}$ & $\mathrm{FISH}$ & Negative & Positive & Chemo, RT & 10 (AFD) \\
\hline Present case & $49 / M$ & Right parotid & 2.7 & $\begin{array}{l}\text { Desmin, EMA, } \\
\text { CK, WT1, } \\
\text { vimentin, } \\
\text { CD56 }\end{array}$ & $\begin{array}{l}\text { FISH、 } \\
\text { RT-PCR }\end{array}$ & Negative & Positive & RT & 36 (AFD) \\
\hline
\end{tabular}

IHC immunohistochemistry, mo month, EMA epithelial membrane antigen, CK cytokeratin, WT1 Wilms tumor 1, NSE neuro-specific enolase, $P R$ progesterone receptor, NS not specified, ND not done, Chemo chemotherapy, $R T$ radiotherapy, DOC died of other complication, $A F D$ alive and free of tumor, DOD died of disease 


\section{Abbreviations}

CK: cytokeratin; CT: Computed tomography; C-WT1: WT1 antibody detecting the C-terminal region; DSRCT: Desmoplastic small round cell tumor; FFPE: formalin-fixed paraffin embedded; FISH: fluorescence in situ hybridization; GFAP: glial fibrillary acid protein; N-WT1: WT1 antibody detecting the C-terminal region; PET: positron emission tomography; RTPCR: reverse transcription polymerase chain reaction; RTU: ready-to-use; SMA: smooth muscle actin; WT1: Wilms tumor 1

\section{Acknowledgments}

The authors thank Ms. Sayaka Honjo and Ms. Asami Okumura for technical supports.

\section{Funding}

Not applicable.

\section{Availability of data and materials}

Data sharing is not applicable to this article as no datasets were generated or analysed during the current study.

\section{Authors' contributions}

$\mathrm{KCH}, \mathrm{ET}, \mathrm{AS}, \mathrm{TM}$, and SM performed pathologic diagnosis and writing of manuscript. SI, NT, and AH collected clinical data and follow-up of the patient. YH performed immunohistochemical and molecular analyses. SS and TH performed pathologic diagnosis and FISH analysis. YM redacted the manuscript. All authors read and approved the final manuscript prior to submission.

\section{Ethics approval and consent to participate}

Approval for this case report was obtained from the Ethical Committee in Hokkaido university hospital. Consent to participate was obtained from the participants.

\section{Consent for publication}

Informed consent was obtained from the patient for the publication of this case report.

\section{Competing interests}

The authors declare that they have no competing interests.

\section{Publisher's Note}

Springer Nature remains neutral with regard to jurisdictional claims in published maps and institutional affiliations.

\section{Author details}

'Department of Surgical Pathology, Hokkaido University Hospital, N14W4, Kita-ku, Sapporo, Japan. ${ }^{2}$ Department of Pathology, KKR, Sapporo Medical Center, 1-6, hiragishi, Toyohira-ku, Sapporo, Japan. ${ }^{3}$ Department of otorhinolaryngology, Hakodate Central General Hospital, 33-2, Honcho, Hakodate, Japan. ${ }^{4}$ Department of Surgical Pathology, Sapporo Medical University School of Medicine, S1W16, chou-ku, Sapporo, Japan. ${ }^{5}$ Department of Otolaryngology-Head \& Neck Surgery, Faculty of Medicine and Graduate School of Medicine, Hokkaido University, N15W7, Kita-ku, Sapporo, Japan.

${ }^{6}$ Department of Diagnostic Pathology, Hino Municipal Hospital, 4-3-1,

Tamadaira, Hino, Tokyo, Japan.

\section{Received: 9 November 2018 Accepted: 13 May 2019}

Published online: 18 May 2019

\section{References}

1. Syed S, Haque AK, Hawkins HK, Sorensen PH, Cowan DF. Desmoplastic small round cell tumor of the lung. Archives of pathology \& laboratory medicine. 2002;126(10):1226-8.

2. Karavitakis EM, Moschovi M, Stefanaki K, Karamolegou K, Dimitriadis E, Pandis $\mathrm{N}$, et al. Desmoplastic small round cell tumor of the pleura. Pediatr Blood Cancer. 2007:49(3):335-8

3. Finke NM, Lae ME, Lloyd RV, Gehani SK, Nascimento AG. Sinonasal desmoplastic small round cell tumor: a case report. Am J Surg Pathol. 2002;26(6):799-803.

4. Neder L, Scheithauer BW, Turel KE, Arnesen MA, Ketterling RP, Jin L, et a. Desmoplastic small round cell tumor of the central nervous system: report of two cases and review of the literature. Virchows Archiv : an international journal of pathology. 2009;454(4):431-9.
5. Lae ME, Roche PC, Jin L, Lloyd RV, Nascimento AG. Desmoplastic small round cell tumor: a clinicopathologic, immunohistochemical, and molecular study of 32 tumors. Am J Surg Pathol. 2002;26(7):823-35.

6. Pang B, Leong CC, Salto-Tellez M, Petersson F. Desmoplastic small round cell tumor of major salivary glands: report of 1 case and a review of the literature. Applied immunohistochemistry \& molecular morphology : AIMM / official publication of the Society for Applied Immunohistochemistry. 2011; 19(1):70-5.

7. Yin WH, Guo SP, Yang HY, Chan JK. Desmoplastic small round cell tumor of the submandibular gland--a rare but distinctive primary salivary gland neoplasm. Hum Pathol. 2010:41(3):438-42.

8. Cho KJ, Ro JY, Choi J, Choi SH, Nam SY, Kim SY. Mesenchymal neoplasms of the major salivary glands: clinicopathological features of 18 cases. European archives of oto-rhino-laryngology : official journal of the European Federation of Oto-Rhino-Laryngological Societies (EUFOS) : affiliated with the German Society for Oto-Rhino-Laryngology - Head and Neck Surgery. 2008;265(Suppl 1):S47-56.

9. Hill DA, Pfeifer JD, Marley EF, Dehner LP, Humphrey PA, Zhu X, et al. WT1 staining reliably differentiates desmoplastic small round cell tumor from Ewing sarcoma/primitive neuroectodermal tumor. An immunohistochemical and molecular diagnostic study. Am J Clin Pathol. 2000;114(3):345-53.

10. Wolf AN, Ladanyi M, Paull G, Blaugrund JE, Westra WH. The expanding clinical spectrum of desmoplastic small round-cell tumor: a report of two cases with molecular confirmation. Hum Pathol. 1999;30(4):430-5.

11. Suehara $Y$, Arcila M, Wang L, Hasanovic A, Ang D, Ito T, et al. Identification of KIF5B-RET and GOPC-ROS1 fusions in lung adenocarcinomas through a comprehensive mRNA-based screen for tyrosine kinase fusions. Clinical cancer research : an official journal of the American Association for Cancer Research. 2012;18(24):6599-608.

12. Lee YS, Hsiao CH. Desmoplastic small round cell tumor: a clinicopathologic, immunohistochemical and molecular study of four patients. Journal of the Formosan Medical Association = Taiwan yi zhi. 2007;106(10):854-60.

13. Gerald WL, Rosai J. Case 2. Desmoplastic small cell tumor with divergent differentiation. Pediatric pathology / affiliated with the International Paediatric Pathology Association. 1989:9(2):177-83.

14. Gerald WL, Ladanyi M, de Alava E, Cuatrecasas M, Kushner BH, LaQuaglia MP, et al. Clinical, pathologic, and molecular spectrum of tumors associated with $\mathrm{t}(11 ; 22)(\mathrm{p} 13 ; \mathrm{q} 12)$ : desmoplastic small round-cell tumor and its variants. Journal of clinical oncology : official journal of the American Society of Clinical Oncology. 1998;16(9):3028-36.

15. Philippe-Chomette P, Kabbara N, Andre N, Pierron G, Coulomb A, Laurence V, et al. Desmoplastic small round cell tumors with EWS-WT1 fusion transcript in children and young adults. Pediatr Blood Cancer. 2012;58(6):891-7.

16. Gnepp DR, Corio RL, Brannon RB. Small cell carcinoma of the major salivary glands. Cancer. 1986;58(3):705-14.

17. Seifert G, Oehne H. Mesenchymal (non-epithelial) salivary gland tumors. Analysis of 167 tumor cases of the salivary gland register. Laryngologie, Rhinologie, Otologie. 1986;65(9):485-91.
Ready to submit your research? Choose BMC and benefit from:

- fast, convenient online submission

- thorough peer review by experienced researchers in your field

- rapid publication on acceptance

- support for research data, including large and complex data types

- gold Open Access which fosters wider collaboration and increased citations

- maximum visibility for your research: over $100 \mathrm{M}$ website views per year

At $\mathrm{BMC}$, research is always in progress.

Learn more biomedcentral.com/submissions 